\title{
The Relationship between Tax Revenue and Economic Growth in Nepal: A Co-integration Approach
}

\author{
Gautam Maharjan'
}

\begin{abstract}
The main objective of this paper is to examine the relationship between tax revenue and economic growth in Nepal. The 43 years' annual time series data from 1974/75 to 2016/17 of GDP, tax revenue and nontax revenue have been used to test the causal relationship of the variables. A unit root test, Engle-Granger's co-integration and Error Correction Model have been applied for the data analysis. The variables have been found stationary after first differencing I(1) when Augmented Dickey-Fuller unit root test is employed. From Engel-Granger test, it has been found that the variables are co-integrated. The short-term coefficients are not significant, however error correction term (ECT) is significant and contains a negative sign in the error correction model (ECM). It validates the ECM model. The ECT has shown that the annual speed of adjustment from disequilibrium to equilibrium is 34.3 percent. So far as the relationship is concerned, there is a long run relationship between tax revenue and economic growth in Nepal controlling the non-tax revenue. The impact of tax revenue on economic growth could be a good impetus for the policy maker and planner to increase the collection of revenue for the country.
\end{abstract}

Key Words: GDP, Tax revenue, Non-tax revenue, ADF test, Enger-Granger Co-integration test

\section{INTRODUCTION}

Tax is a kind of mandatory payment to the government by individuals or institutions in exchange for services render indirectly to the public by the government. The basic objective of tax system is to finance public expenditures. Tax system also plays a vital role in achieving other targets like equity, social and economic justice in the economy. A well organized, efficient and effective tax system is a pre-requisite for economic growth. Tax

1. Dr. Maharjan is Faculty Mamber at Public Youth Campus, Tribhuvan University. He can be reached at maharjangautam@gmail.com 
determines the level and speed of economic growth in countries of the globe (Omojemite \& Godwin, 2012).

Of the targeted gross revenue mobilization of Rs 565.90 billion in the fiscal year $2016 / 17$ in Nepal, only Rs 353.91 billion was mobilized in the first eight months. This is 53.16 percent higher than that of the corresponding period of the last previous fiscal year $2015 / 16$. Of the total revenue collection, the share of tax revenue was 93.18 percent while the non-tax revenue was 6.82 percent. The ratio of revenue to GDP was 21.45 percent in previous fiscal year 2015/16 (Ministry of Finance, 2017).

Numerous studies have revealed the empirical relationships between tax revenue and economic growth. The relationships between tax revenue and economic growth were found in a number of empirical studies in the past. However, the previous empirical studies found different and disaggregated results. For instance, Anyanwu (1997); Ogbonna and Appah (2012); Yaya (2013); Akwe (2014) indicated positive relationship between taxation and economic growth, others, Saibu (2015); Gareth (2000); Bonu and Pedro (2009); Saima, Tariq, Muhammad, Sofia and Amir (2014) showed negative relationship. Similary, Barro (1991), Plosser (1992), and King and Rebelo (1990) suggested that a growth in tax volume leads to a reduction in growth while Kneller et al. (1999), Slemrod and Yitzhaki (1995) and Levine and Renelt (1992) reported an insignificant or even positive correlation between tax and growth. Onakoya and Afintinni (2016) found in their study that a long run (but not short run) relationship existed between taxation and economic growth in Nigeria.

In this way, the studies testing empirically the relationship between taxation and economic growth found a positive as well as negative impact of the aggregate tax on economic growth. But some others like Essoh (2011) suggested no significant relationship between these two major variables. For data analysis, some studies applied the single ordinary least square estimating technique, others utilised co-integration tests, unit root tests, and descriptive techniques.

Considering the dissimilar findings in the previous studies, this study seeks to further investigate both the short run and the long run relationships between tax revenue and economic growth in Nepal. The selected the study period provides an opportunity for a comprehensive assessment of the effect of tax revenue on the Nepalese economy.

The aim of this study is to investigate the long run equilibrium relationships between overall tax revenues and economic growth in Nepal using the co-integration approach. Effective taxation is a part of economic policy, but successful implementation has been a great challenge in Nepal in the current situation. For the last couple of decades, Nepalese economy has been showing a lacklustre result owing to fiscal inadequacies leading to macro-economic instability over the years. Thus, this issue demands further attention of researchers.

Tax revenue is an important source of government revenue in Nepal. As a developing country, Nepal has been relying heavily on the tax revenue for the government funding. Hence, the effective tax system is important to attract domestic and foreign investors.

The study of Nepal's tax regime and its impact on long-term economic growth will 
provide an insight on how changes in fiscal policy are likely to increase the pace of Nepal's economic growth. In particular, the statistical significance of key elements in determining Nepal's economic growth is expected to shed light on the linkage between tax revenues and economic growth and how mutual causality can impact the inter-temporal economic development for the current and future generations. This will be useful to policy makers who will ensure prudent use of tax revenues to achieve economic growth.

\section{OBJECTIVES}

The main objective of the study is to analyse the causal relationships between tax revenue and the economic growth in Nepal. Other specific objectives are to examine the long run relationships between tax revenue and economic growth and to identify the speed of adjustment from disequilibrium to equilibrium in long run over the period.

\section{METHODOLOGY}

The research design of the study is causal comparative. This design has been adopted to analyse the impact of tax revenue on economic growth. Natural log of real GDP ( $\left(n R G D P_{t}\right)$ is taken as a dependent variable for economic growth, whereas natural log of real tax revenue $\left(\operatorname{InRTR}_{t}\right)$ and natural log of real non-tax revenue $\left(\operatorname{InRNTR}_{t}\right)$ are taken as independent variables. Non-tax revenue is used as controlling variable to analyse the impact of tax revenue on economic growth.

The 43 years annual time series data from 1974/75 to 2016/17 are used for the study. Three variables are converted from nominal price to constant price using GDP deflator at base year 2000/01. The stationarity has been tested using Augmented Dickey-Fuller (ADF) unit root tests. Engle-Granger's co-integration has been used to test the long run relationship between tax revenue and economic growth. Error Correction Model (ECM) is also used to identify the speed of adjustment from disequilibrium to equilibrium in long run. It is expected that the error correction term (ECT) should be significant and have negative sign to validate that there exists a long run relationship among the variables in the model. The following models have been developed for the data analysis.

\section{Augmented Dickey-Fuller (ADF) Test}

If $\delta$ equals to zero in equation (1), the null hypothesis will be rejected. This indicates that the time series has no unit root or data are stationary (Gujarati \& Sangeetha, 2007).

$$
\Delta \mathrm{Y}_{\mathrm{t}}=\beta_{\mathrm{1}}+\beta_{2} \mathrm{t}+\delta \mathrm{Y}_{\mathrm{t}-1}+\sum_{i=1}^{m} \alpha_{i} \Delta \mathrm{Y}_{\mathrm{t}-\mathrm{i}}+\varepsilon_{\mathrm{t}}
$$

Where et a pure white noise error term and DYt-i equals (DYt-1- DYt-2), (DYt2-DYt-3), etc. The number of lagged difference terms to include is often determined empirically, the idea being to include enough terms so that the error term in equation (1) above is serially uncorrelated (Gujarati \& Sangeetha, 2007). 


\section{Engle Granger's Co-integration Model}

Unit root test has been performed using ADF test on residual of equation (2) in equation (3). But ADF critical value is not quite appropriate to test the unit root in residual. So, Engle-Granger critical $t$ value is used to test unit root in residual. Therefore ADF test in the present context is known as Engle-Granger test (Gujarati \& Sangeetha, 2007).

$$
\begin{aligned}
& \operatorname{lnRGDP} \mathrm{t}_{\mathrm{t}}=\alpha+\beta_{l} \operatorname{lnRTR} \mathrm{t}_{\mathrm{t}}+\beta_{2} \ln \operatorname{RNTR}_{\mathrm{t}}+\mathrm{U}_{\mathrm{t}} \\
& \Delta \mathrm{U}_{\mathrm{t}}=\beta \mathrm{U}_{\mathrm{t}-1}+\varepsilon_{\mathrm{t}}
\end{aligned}
$$

Where, In refers to natural log, RGDP refers real GDP, RTR refers real tax revenue, RNTR refers to real non-tax revenue, U refers to error term, trefers to time period, $\Delta \mathrm{U}_{t}$ refers to $\left(\Delta \mathrm{U}_{\mathrm{t}-1}-\Delta \mathrm{Y}_{\mathrm{t}}\right), \mathrm{U}_{\mathrm{t}-1}$ refers the error term of one lag period and $\varepsilon$ refers to error term for equation (3).

\section{Error Correction Model}

The Granger representation theorem states that if two variables $X$ and $Y$ are cointegrated, then the relationship between the two can be expressed as Error Correction Model (Gujarati \& Sangeetha, 2007). The following equation (4) has been set for error correction model.

$$
\Delta \operatorname{lnRGDP}_{\mathrm{t}}=\alpha+\beta_{I} \Delta \operatorname{lnRTR}{ }_{\mathrm{t}}+\beta_{2} \Delta \operatorname{lnRNTR}+\beta_{3} \mathrm{U}_{1-1}+\varepsilon_{t}
$$

Where $\triangle \mathrm{InRGDP}$ refers to change in natural log of GDP, $\triangle \mathrm{InRTR}$ refers to change in natural log of real tax revenue, $\triangle$ InRNTR refers to natural log of real non-tax revenue, $U_{t-1}$ refers to error term of one lag period and $\varepsilon$ refers to error term in the current equation. The coefficient $\beta_{3}$ is expected to be negative so that disequilibrium could be corrected in the long run. So, it is also known as error correction term (ECT).

\section{LIMITATIONS}

In order to conduct the study, only quantitative data has been collected from the secondary sources. The study has used only time series data from 1974/75 to 2016/17 in the study. Only Engle-Granger's Co-integration test has been used to analyse the long run relationship between the variables in this study. More other sophisticated tools have not been used to test the impact of tax revenue in economic growth.

\section{RESULTS AND DISCUSSION}

\section{Unit Root Test on InRGDP, InRTR and InRNTR}

From the Augmented Dickey-Fuller (ADF) test in level data, Table 1 shows that all ADF statistics of InRGDP, InRTR and InRNTR are less than T-critical at 5 percent level. This indicates that these three variables are not significant at 5 percent. So, these 
variables have unit root at level. Therefore, these three variables are not stationary at level.

Table 1: Augmented Dickey-Fuller Test

\begin{tabular}{ccccccc}
\hline & Variables & ADF Statistic & $\begin{array}{c}\text { T-critical @ } \\
\mathbf{5 \%}\end{array}$ & $\begin{array}{c}\text { Order of } \\
\text { Integration }\end{array}$ & & \\
\hline \multirow{3}{*}{ Data at Level } & InRGDP & -1.633 & -3.527 & $\mathrm{I}(0)$ & ADF <T-crit & Insignificant \\
& InRTR & -2.602 & -3.521 & $\mathrm{I}(0)$ & ADF <T-crit & Insignificant \\
& InRNTR & -1.544 & -3.521 & $\mathrm{I}(0)$ & ADF $<$-crit & Insignificant \\
Data after first & $\Delta$ InRGDP & -7.837 & -3.527 & $\mathrm{I}(1)$ & ADF $>$ T-crit & Significant \\
Differencing & $\Delta$ InRTR & -4.952 & -3.524 & $\mathrm{I}(1)$ & ADF $>$ T-crit & Significant \\
& $\Delta$ InRNTR & -3.879 & -3.540 & $\mathrm{I}(1)$ & ADF $>$ T-crit & Significant \\
\hline
\end{tabular}

After first differencing InRGDP, InRTR and InRNTR, ADF test is again performed. Table 1 shows that all ADF statistics of $\triangle \mathrm{InRGDP}, \Delta \mathrm{InRTR}$ and $\triangle \mathrm{InRNTR}$ are greater than $\tau$-critical at 5 percent level. This indicates that these three variables have no unit root. Hence, InRGDP, InRTR and InRNTR are stationary after first differencing I(1).

\section{Causal Relationship between Tax Revenue and Economic Growth}

For regression analysis, InRGDP is taken as a dependent variable, whereas InRTR and InRNTR are taken as independent variables. Model 1 shows the impact of tax revenue (InRTR) on economic growth (InRGDP) controlling impact of non-tax revenue (InRNTR) in the model.

Model 1 shows that R-squared value 0.983 and DW is 1.406 . Since R-squared value is less than DW, the model is fit. R-squared value shows that 98.3 percent variation in InRGDP is explained by variation in InRTR and InRNTR. The value of F-statistic is 1189.031 and its corresponding $p$-value is 0.000 which is less than $0.05(5 \%)$. This indicates that F-statistic is significant at 5 percent level. Since corresponding $p$-value of F-statistic is significant, the model is fit.

In the Model 1, coefficients of $\operatorname{InRTR}_{t}$ and $\operatorname{InRNTR}_{t}$ are 0.486 and 0.202 respectively. The corresponding t-statistics of them are also 13.068 ( $p$-value: 0.000 ) and 4.4829 ( $p$-value: 0.000 ) respectively. Since corresponding $p$-values are less that $0.05(5 \%)$, both variables are significant at 5 percent level. Table 1 has already showed that InRGDP, InRTR and InRNTR are not stationary at level, however both variables are stationary after first differencing I(1). This indicates that Model 1 as shown in Table 2 is a long run model.

Since corresponding p-value of $\operatorname{InRTR}_{t}$ and InRNTR are less than $0.05(5 \%)$, the t-statistics are significant at 5 percent level. This indicates that there is a significant impact of real tax revenue on real GDP. So far as the relationship between InRGDP and $\operatorname{InRTR}_{t}$ are concerned, the coefficient of $\operatorname{InRTR}_{t}(0.486)$ is long run coefficient in the model. The coefficient of InRTR $\mathrm{t}_{\mathrm{t}}$ shows that one percent change in real tax revenue leads to 0.486 percent change in real GDP (economic growth) over the period. 
Table 2: Regressing InRGDP on InRTR and InRNTR

\begin{tabular}{ccccc}
\hline \multicolumn{1}{c}{ Variable } & Coefficient & Std. Error & t-Statistic & p-value \\
\hline Constant & 5.239 & 0.108 & 48.570 & 0.000 \\
InRTR $_{\mathrm{t}}$ & 0.486 & 0.037 & 13.068 & 0.000 \\
InRNTR $_{\mathrm{t}}$ & 0.202 & 0.042 & 4.829 & 0.000 \\
\hline Model 1: InRGDP & $=5.239+0.486 \operatorname{lnRTR}_{\mathrm{t}}+0.202 \operatorname{lnRNTR}{ }_{\mathrm{t}}+\mathrm{U}_{\mathrm{t}}$ & \\
\hline $\mathrm{R} 2: 0.983$ & $\mathrm{~F}$-statistic: 1189.031 (p-value: 0.000$)$ & \\
DW: 1.406 & $\mathrm{~N}: 43$ & df: 2,40 & \\
\hline
\end{tabular}

\section{Unit Root Test on Error Term}

As shown in Table 3, the unit root on error term of Model 1 has been tested. It depicted that value of Engle-Granger $(E-G)$ statistic of error term $\left(U_{t}\right)$ is -4.583 and its corresponding $\tau$-critical value is -3.740 at 5 percent level. Since E-G statistic is less than its corresponding $\tau$-critical value, it is significant at 5 percent level. This means that error term $\left(U_{t}\right)$ in the Model 1 has no unit root and is stationary. When error term becomes stationary, InRGDP, InRTR and RNTR are co-integrated. So far as the relationship is concerned, tax revenue and economic growth have a long run relationship controlling non-tax revenue.

Table 3: Engle Granger Test

\begin{tabular}{ccccc}
\hline \multirow{2}{*}{ Variables } & E-G & T -critical & & \\
& Statistic & @ 5\% & & \\
\hline$U t$ & -4.583 & -3.740 & E-G >T-crit & Significant \\
\hline
\end{tabular}

\section{Error Correction Model}

It is proved that InRTR and InRNTR are co-integrated with InRGDP in Model 1. This indicated that there is a long run relationship of InRGDP with InRTR and InRNTR. So, error correction model can be run. Table 4 shows the error correction model as Model 2 where $\Delta \ln G D P$ dependent variable and $\Delta \operatorname{lnRTR}, \Delta \operatorname{lnRNTR}$ and $U_{t-1}$ are the independent variables. In the model, InRGDP refers to real gross domestic product (economic growth), InRTR refers to real tax revenue, and RNTR refers to real non-tax revenue. These three variables are stationary after first differencing. So, $\Delta$ sign refers to first differencing.

Similarly, $U_{t-1}$ refers to one period lag of residual which is also known as error correction term (ECT) and et refers to error term in Model 2. The coefficients of $\triangle \mathrm{InRTR}$ and $\triangle$ InRNTR in Model 2 are short run coefficients and corresponding t-statistics are not significant because their $p$-values are more than $0.05(5 \%)$. But the coefficient of error correction term $\left(U_{t-1}\right)$ is the long run coefficient. Since the corresponding $p$-value is less than $0.05(5 \%)$, the ECT is significant at 5 percent level. The value of the coefficient is -0.343 . The negative sign (-) indicates the error correction term is correcting the disequilibrium in system. This shows that the speed at adjustment is 34.3 percent. This means that error correction term is correcting the disequilibrium at 34.3 percent annually. 
In this model, corresponding p-values of short term coefficients of $\Delta \operatorname{lnRTR}$ and $\Delta \operatorname{lnRNTR}$ are more than $0.05(5 \%)$. So, these coefficients are not significant at 5 percent level. However the long run coefficient of $\mathrm{U}_{\mathrm{t}-1}$ is significant with negative sign. Therefore, error correction term (coefficient of $U_{t-1}$ ) is correcting the disequilibrium in long run.

Table 4: Regressing $\Delta \operatorname{lnRGDPt}$ on $\Delta \operatorname{lnRTRt}, \Delta \operatorname{lnRNTRt}$, and $\mathrm{U}_{\mathrm{t}-1}$

\begin{tabular}{|c|c|c|c|c|}
\hline Variable & Coefficient & Std. Error & t-Statistic & $p$-value \\
\hline Constant & 0.036 & 0.008 & 4.279 & 0.000 \\
\hline$\Delta \operatorname{lnRTR} R_{t}$ & 0.095 & 0.083 & 1.145 & 0.260 \\
\hline$\Delta \operatorname{lnRNTR}{ }_{t}$ & 0.009 & 0.036 & 0.252 & 0.803 \\
\hline$U_{t-1}$ & -0.343 & 0.115 & -2.983 & 0.005 \\
\hline
\end{tabular}

R2: $0.201 \quad$ F-statistic: 3.193 (p-value: 0.034 )

DW: $2.232 \quad \mathrm{~N}: 42 \quad \mathrm{df}: 3,38$

\section{CONCLUSION}

The tax revenue, non-tax revenue and economic growth are co-integrated over the period from 1974/75 to 2016/17 in Nepal. Controlling the effect of non-tax revenue, it is confirmed that there is a positive long run relationship between tax revenue and economic growth. The result of this study has been found similar with Onakoya and Afintinni (2016), Anyanwu (1997); Ogbonna and Appah (2012); Yaya (2013); Akwe (2014), but contradicts with the study of Saibu (2015); Gareth (2000); Bonu and Pedro (2009); Saima et al. (2014).

The error correction term (ECT) shows that there is a speed of adjustment from disequilibrium to equilibrium is 34.3 percent annually. So, the ECT is correcting the disequilibrium of relationship in long run over the period. From the error correction model, it is showed that the short-run coefficients of change in real tax revenue and change in non-tax revenue are not significant.

However, error correction term is significant and contains negative sign. Therefore, it validates that there exists a long run relationship between the variables in the model. So far as the relationships are concerned, it can be confirmed that there is a long run relationship between tax revenue and economic growth. Therefore the policy maker and planner have to make a good framework to enhance the collection of tax for economic growth in long-term.

\section{REFERENCES}

Akwe, J. A. (2014). Impact of non-oil tax revenue on economic growth: The Nigerian perspective. International Journal of Finance and Accounting, 3(5), 303-309.

Anyanwu, J. C. (1997). Nigeria public finance. Onitsha: Joance Education Publishers.

Barro, R. J. (1991). Economic growth in a cross-section of countries. Quarterly Journal of Economics, 106, 407-441.

Bonu, N. S., \& Pedro, M. P. (2009). The impact of income tax rates (ITR) on the economic development of Botswana. Journal of Accounting and Taxation, 1(1), 008-022. 
Essoh, F. (2011). Effects of corporate taxes on economic growth: The case of Sweden (Bachelor's thesis). Jonkoping International Business School, Jönköping University.

Gareth, D. M. (2000). Taxation and economic growth. Fiscal Studies, Institute for Fiscal Studies, 21(1), 141-168.

Gujarati, D. N., \& Sangeetha, G. (2007). Basic econometrics (4 ${ }^{\text {th }}$ ed.). New Delhi: Tata McGraw Hill Education.

King, R. G., \& Rebelo, S. (1990). Public policy and economic growth: developing neoclassical implications. Journal of Political Economy, 98, 126-150.

Levine, R., \& Renelt, D. (1992). A sensitivity analysis of cross-country growth regressions. American Economic Review, 82, 942-963.

Ministry of Finance. (2017). Economic survey 2016/17. Kathmandu: Government of Nepal.

Ogbonna, G. N., \& Appah, E. (2012). Impact of tax reforms and economic growth in Nigeria: A time series analysis. Current Research Journal of Social Sciences, 4(1), 62-68.

Omojemite, U., \& Godwin, I. (2012). Fiscal deficit and the productivity of the Nigeria tax system 1970-2010. Journal of sustainable development, 5(4), 116-125.

Onakoya, A. B., \& Afintinni, O. I. (2016). Taxation and economic growth in Nigeria. Asian Journal of Economic Modelling, 4(4), 199-210.

Plosser, C. I. (1992). The search for growth. Proceedings-Economic Policy Symposium-Jackson Hole, (pp. 57-86). Kansas City: Federal Reserve Bank of Kansas City.

Saima, S., Tariq, A., Muhammad, F. R., Sofia A., \& Amir, A. (2014). Taxation effects on economic activity in Pakistan. Journal of Finance and Economics, 6(2), 215-219.

Slemrod, J., \& Yitzhaki, S. (1995). The costs of taxation and the marginal cost of funds (Working Paper 83). International Monetary Fund.

Yaya, K. (2013). The structure of taxes and economic growth in Cote D'Ivoire: An econometric investigation. Journal of Research in Economics and International Finance, 3(2), 39-48. 
36 I PYC Nepal Journal of Management, August 2018, Vol. XI, No. 1

\section{Annex}

\section{Annex 1: Annual Time Series Data of GDP, Tax Revenue, Non-tax Revenue and GDP Deflator}

NPR in 10 Million

\begin{tabular}{|c|c|c|c|c|c|c|c|c|c|}
\hline Fiscal Year & $\begin{array}{c}\text { GDP } \\
\text { (NPR) }\end{array}$ & $\begin{array}{c}\text { Tax_Rev } \\
\text { (NPR) }\end{array}$ & $\begin{array}{c}\text { Non } \\
\text { Tax_Rev } \\
\text { (NPR) }\end{array}$ & $\begin{array}{c}\text { GDP_Def } \\
\text { Base Year } \\
2000 / 01\end{array}$ & Fiscal Year & $\begin{array}{l}\text { GDP } \\
\text { (NPR) }\end{array}$ & $\begin{array}{c}\text { Tax_Rev } \\
\text { (NPR) }\end{array}$ & $\begin{array}{c}\text { Non } \\
\text { Tax_Rev } \\
\text { (NPR) }\end{array}$ & $\begin{array}{c}\text { GDP_Def } \\
\text { Base Year } \\
2000 / 01\end{array}$ \\
\hline $1974 / 75$ & 1,660 & 84 & 17 & 12.64 & $1996 / 97$ & 28,051 & 2,442 & 595 & 76.24 \\
\hline $1975 / 76$ & 1,739 & 91 & 21 & 12.78 & $1997 / 98$ & 30,085 & 2,594 & 700 & 79.27 \\
\hline $1976 / 77$ & 1,728 & 110 & 22 & 12.49 & $1998 / 99$ & 34,204 & 2,875 & 850 & 86.31 \\
\hline $1977 / 78$ & 1,973 & 124 & 34 & 13.81 & $1999 / 00$ & 37,949 & 3,315 & 974 & 90.27 \\
\hline $1978 / 79$ & 2,613 & 148 & 33 & 15.30 & $2000 / 01$ & 44,152 & 3,887 & 1,003 & 100.00 \\
\hline $1979 / 80$ & 2,335 & 154 & 35 & 16.02 & $2001 / 02$ & 45,944 & 3,933 & 1,112 & 103.90 \\
\hline $1980 / 81$ & 2,553 & 204 & 38 & 17.20 & $2002 / 03$ & 49,223 & 4,090 & 1,364 & 107.11 \\
\hline $1981 / 82$ & 3,099 & 221 & 47 & 18.62 & $2003 / 04$ & 53,675 & 4,817 & 1,416 & 111.44 \\
\hline $1982 / 83$ & 3,382 & 243 & 42 & 20.07 & $2004 / 05$ & 58,941 & 5,410 & 1,602 & 117.95 \\
\hline $1983 / 84$ & 3,929 & 274 & 67 & 21.53 & $2005 / 06$ & 65,408 & 5,743 & 1,485 & 126.18 \\
\hline $1984 / 85$ & 4,659 & 315 & 77 & 22.73 & $2006 / 07$ & 72,783 & 7,113 & 1,659 & 135.38 \\
\hline $1985 / 86$ & 5,573 & 366 & 99 & 25.98 & $2007 / 08$ & 81,566 & 8,516 & 2,247 & 142.94 \\
\hline $1986 / 87$ & 6,386 & 437 & 160 & 29.23 & $2008 / 09$ & 98,827 & 11,705 & 2,642 & 165.77 \\
\hline $1987 / 88$ & 7,691 & 575 & 160 & 32.68 & $2009 / 10$ & 119,277 & 15,629 & 2,365 & 189.56 \\
\hline $1988 / 89$ & 8,927 & 629 & 149 & 36.37 & $2010 / 11$ & 136,695 & 17,278 & 2,704 & 210.34 \\
\hline $1989 / 90$ & 10,342 & 728 & 203 & 40.29 & $2011 / 12$ & 152,734 & 21,172 & 3,265 & 224.13 \\
\hline $1990 / 91$ & 12,037 & 818 & 255 & 44.00 & $2012 / 13$ & 169,501 & 25,921 & 3,681 & 237.77 \\
\hline $1991 / 92$ & 14,949 & 988 & 364 & 52.35 & $2013 / 14$ & 196,454 & 31,244 & 4,418 & 259.18 \\
\hline $1992 / 93$ & 17,149 & 1,166 & 349 & 57.72 & $2014 / 15$ & 213,015 & 35,596 & 4,991 & 272.41 \\
\hline $1993 / 94$ & 19,927 & 1,537 & 421 & 61.98 & $2015 / 16$ & 224,743 & 42,110 & 6,087 & 285.93 \\
\hline $1994 / 95$ & 21,918 & 1,966 & 495 & 65.95 & $2016 / 17$ & 259,923 & 32,976 & 2,415 & 308.80 \\
\hline $1995 / 96$ & 24,891 & 2,167 & 623 & 1.10 & & & & & \\
\hline
\end{tabular}

Source: Various Economic Surveys, Ministry of Finance, Government of Nepal. 